\title{
Tissue Physiology of Cynomolgus Monkeys: Cross-Species Comparison and Implications for Translational Pharmacology
}

\author{
Danielle Mandikian, ${ }^{1}$ Isabel Figueroa, ${ }^{1}$ Amy Oldendorp, ${ }^{2}$ Hanine Rafidi, ${ }^{1}$ Sheila Ulufatu, ${ }^{2}$ \\ Michelle G. Schweiger, ${ }^{2}$ Jessica A. Couch, ${ }^{2}$ Noel Dybdal, ${ }^{2}$ Sean B. Joseph, ${ }^{1}$ Saileta Prabhu, ${ }^{1}$ \\ Gregory Z. Ferl, ${ }^{1,3,4}$ and C. Andrew Boswell ${ }^{1,3,4}$
}

Received 1 August 2018; accepted 10 September 2018; published online 8 October 2018

\begin{abstract}
We previously performed a comparative assessment of tissue-level vascular physiological parameters in mice and rats, two of the most commonly utilized species in translational drug development. The present work extends this effort to non-human primates by measuring tissue- and organ-level vascular volumes $\left(V_{\mathrm{v}}\right)$, interstitial volumes $\left(V_{\mathrm{i}}\right)$, and blood flow rates $(Q)$ in cynomolgus monkeys. These measurements were accomplished by red blood cell labeling, extracellular marker infusion, and rubidium chloride bolus distribution, respectively, the same methods used in previous rodent measurements. In addition, whole-body blood volumes (BV) were determined across species. The results demonstrate that $V_{\mathrm{v}}, V_{\mathrm{i}}$, and $Q$, measured using our methods scale approximately by body weight across mouse, rat, and monkey in the tissues considered here, where allometric analysis allowed extrapolation to human parameters. Significant differences were observed between the values determined in this study and those reported in the literature, including $V_{\mathrm{v}}$ in muscle, brain, and skin and $Q$ in muscle, adipose, heart, thymus, and spleen. The impact of these differences for selected tissues was evaluated via sensitivity analysis using a physiologically based pharmacokinetic model. The blood-brain barrier in monkeys was shown to be more impervious to an infused radioactive tracer, indium-111-pentetate, than in mice or rats. The body weight-normalized total BV measured in monkey agreed well with previously measured value in rats but was lower than that in mice. These findings have important implications for the common practice of scaling physiological parameters from rodents to primates in translational pharmacology.
\end{abstract}

KEY WORDS: allometric scaling; non-human primates; physiologically based pharmacokinetic modeling; tissue physiological parameters; translational pharmacology.

\section{INTRODUCTION}

The scaling of various physiological parameters across species has been performed for several decades, largely for the purpose of translational pharmacology [1-6]. Knowledge

Danielle Mandikian and Isabel Figueroa contributed equally to this work.

Electronic supplementary material The online version of this article (https://doi.org/10.1208/s12248-018-0264-z) contains supplementary material, which is available to authorized users.

${ }^{1}$ Preclinical and Translational Pharmacokinetics, Genentech Research and Early Development, South San Francisco, California 94080, USA.

${ }^{2}$ Safety Assessment, Genentech Research and Early Development, South San Francisco, California 94080, USA.

${ }^{3}$ Genentech Inc., 1 DNA Way MS 463a, South San Francisco, California 94080, USA.

${ }^{4}$ To whom correspondence should be addressed. (e-mail: ferl.gregory@gene.com; boswell.andy@gene.com) of physiological parameters is required for derivation of drug concentrations within compartments such as interstitial fluid (often the drug site of action, particularly for biologics) [7-9] and is an important component of many physiologically based pharmacokinetic (PBPK) models [10-18]. Human tissue/ organ-level physiological parameters are often derived by allometric scaling of corresponding animal data ( $[5,19,20])$. For biologic drugs with minimal cell partitioning (e.g., antibodies), blood correction of whole tissue concentrations and subsequent conversion into interstitial fluid concentrations requires knowledge of the fractional composition of vascular and interstitial spaces, respectively, within each tissue $[7,8]$. We previously reported measurement of tissuelevel vascular volumes $\left(V_{\mathrm{v}}\right)$, interstitial volumes $\left(V_{\mathrm{i}}\right)$, and rates of blood flow $(Q)$ in several immunocompromised mouse strains [21-25]. More recently, we expanded our investigations to include immunocompetent mice [26, 27] and rats [28], but comparable experimental data in primates remains unavailable for some parameters (e.g., $V_{\mathrm{i}}$ ) and is 
reported only in limited tissues for others. The cynomolgus monkey is often the nonclinical species of choice, particularly in antibody development, for a number of reasons: the higher degree of target homology with human makes interspecies cross-reactivity more likely, the increased pharmacological and toxicological relevance in cases where target biology is similar to human, and the availability of robust, highly validated methods for predicting clinical pharmacokinetics based on monkey studies. Additionally, generating more accurate and methodologically consistent physiological parameter values will improve preclinical to clinical allometric scaling, prospective clinical PK/PD simulations, and other related calculations (e.g., predicting target-mediated drug disposition based on observed/assumed volumes of distribution), potentially resulting in decreased animal usage. Herein, we address this gap by measuring the same three parameters in cynomolgus monkeys using identical experimental approaches as were used in rodents $[8,28]$. In addition, total blood volumes (BV) were calculated for monkey and rodents (using current and historical data, respectively) to gain a further quantitative understanding of vascular physiological parameters across these species commonly used in drug development.

Accurate measurement of $V_{\mathrm{v}}$ (i.e., residual blood volume) in tissues requires the use of very large molecules that are unable to extravasate (Fig. 1). Radiolabeled albumin or immunoglobulin uptake should not be used to estimate $V_{\mathrm{v}}$ as these molecules are known to exhibit transudation (i.e., extravasation) into interstitial spaces of tissues even at early time points [29]. Consequently, we selected a red blood cell (RBC) radiolabeling method that relies on stannous ion $\left(\mathrm{Sn}^{+2}\right)$-mediated reduction of technetium [30]. After priming RBCs with $\mathrm{Sn}^{+2}$ (often termed pre-tinning), technetium in the form of pertechnetate ion $\left({ }^{99 \mathrm{~m}} \mathrm{TcO}^{4-}\right)$ is introduced and becomes reduced by $\mathrm{Sn}^{+2}$ leading to stable binding to the beta chain of hemoglobin with high labeling efficiency. A similar protocol is used for clinical blood pool imaging [31] and has been back-translated for measuring $V_{\mathrm{v}}$ in mouse xenograft models [32]. However, the portion of ${ }^{99 \mathrm{~m}} \mathrm{TcO}^{4-}$ that does not bind hemoglobin can skew $V_{\mathrm{v}}$ measurements in tissues since extravasation of unbound ${ }^{99} \mathrm{TcO}^{4-}$ into tissues exaggerates the number of ${ }^{99 \mathrm{~m}} \mathrm{Tc}$-labeled RBCs present. To address this issue, we modified the clinical in vivo procedure for quantitative $V_{\mathrm{v}}$ measurement in rodent tissues using a transfusion approach in which pre-tinning, ${ }^{99} \mathrm{TcO}^{4-}$ labeling (at high specific activity), and purification (via extravasation and/or renal filtration) occur in a donor animal $[21,22,26,28]$. The ${ }^{99 \mathrm{~m}}$ Tc-labeled blood from this donor can be subsequently collected at euthanasia and carefully reinjected into naïve animals for $V_{\mathrm{v}}$ determination. In addition to providing $V_{\mathrm{v}}$ measurements at the tissue level, data from RBC labeling can also be used to calculate hematocrit [33] and total BV $[34,35]$.

Historically, measurement of $V_{\mathrm{i}}$ has relied on the use of several small molecules as extracellular tracers, including sucrose, inulin, chloride, sulfate, and the radiometalpolyaminopolycarboxylate complex chromium-51ethylenediaminetetraacetic acid $\left({ }^{51} \mathrm{Cr}\right.$-EDTA) [36, 37]. More recently, preclinical measurement of interstitial volume in tumors has been accomplished by indium-111-labeled diethylenetriamine pentaacetate (i.e., ${ }^{111}$ In-pentetate or ${ }^{111}$ In-DTPA) [38, 39]. Such measurements rely on two assumptions: (1) tracer is excluded from all living cells (an appropriate assumption for a polar, charged molecule like ${ }^{111}$ In-DTPA) and (2) tracer is in steady-state equilibrium between plasma and interstitial fluid at time of measurement (Fig. 1). In preclinical studies, others have either suppressed renal filtration (nephrectomy, renal ligature) or applied a constant infusion of tracer in order to maintain constant plasma levels and accurately derive $V_{\mathrm{i}}$ values in selected tissues [37]. We previously employed constant intravenous infusion of ${ }^{111}$ In-DTPA followed by prompt euthanasia and tissue harvest [21, 26, 28]. This approach allows us to measure $V_{\mathrm{i}}$ in most tissues except brain and eye (because ${ }^{111}$ In-DTPA is excluded) and kidneys (because ${ }^{111}$ In-DTPA is excreted).

Measurement of $Q$ (blood flow rate) utilizes certain tracers such as the noble gas xenon (Xe) [40] and alkali metal ions $\left(\mathrm{K}^{+} / \mathrm{Rb}^{+}\right)$[41] that are completely extracted by tissues from circulating blood on first pass, such that extravascular tracer levels in each tissue shortly after tracer administration can be used to approximate blood flow rate to that tissue as a fraction of cardiac output (Fig. 1). This rapid extraction phenomenon has been exploited to measure $Q$ in tumors and other tissues preclinically [32, 42-44], with further efforts for clinical translation via ${ }^{81} \mathrm{Rb}$ positron emission tomographic imaging in patients [45]. The absence of significant $\mathrm{Rb}^{+}$ washout following extraction is due, in part, to its active transport into cells via $\mathrm{Na}-\mathrm{K}$ pumps (i.e., $\mathrm{Na}^{+} / \mathrm{K}^{+}$-ATPases) [46], particularly in cardiac myocytes [47]. Consistent with this concept, the amount of measured ${ }^{42} \mathrm{~K}^{+}$and ${ }^{86} \mathrm{Rb}^{+}$has been shown to be relatively constant from as early as $9 \mathrm{~s}$ to as late as $120 \mathrm{~s}$ post administration [41]. The two most common indicators for measuring regional blood flow rates (i.e., relative distribution of cardiac output to various tissues) are radiolabeled microspheres and the radioactive potassium ion analogue ${ }^{86} \mathrm{Rb}^{+}$. A direct comparison of these two methods yielded largely similar results in rat [48]. Most preclinical reports on methods for measuring $\mathrm{Q}$ have been limited to xenograft tumors and a few selected tissues, although compilations of data across species are available [49]. However, the use of various techniques and/or strains has thereby motivated extension of this approach to measure $\mathrm{Q}$ in a much wider range of tissues in mice [26] and rats [28]; however, brain and eye should be excluded due to exclusion of ${ }^{86} \mathrm{Rb}$ by the blood-brain and blood-ocular barriers [50].

Using the aforementioned techniques, we measured $V_{\mathrm{v}}$, $V_{\mathrm{i}}$, and $Q$ in vivo across a wide range of tissues in mice, rats, and monkeys for the purpose of informing translational pharmacology as well as physiologically based pharmacokinetic (PBPK) modeling efforts. A recently published PBPK model [13] compiled a list of previously measured (or scaled/ assumed) $V_{\mathrm{v}}, V_{\mathrm{i}}$, and $Q$ values from a diverse set of published literature $[17,18,51-53]$ for the species considered here; however, as is typical in PBPK modeling efforts, these values were obtained using a wide variety of experimental techniques or were scaled from other species in cases where measured values were unavailable. In some cases, nominal values (e.g., 10\% vascular volume for well-perfused tissues) were assumed based on little to no experimental data for the specific organ of interest [17]. In this study, we aim to address (1) the limited availability of tissue-level parameters in primates [18], where scaled or nominal values are often used when measured values are unavailable and (2) reduce the 


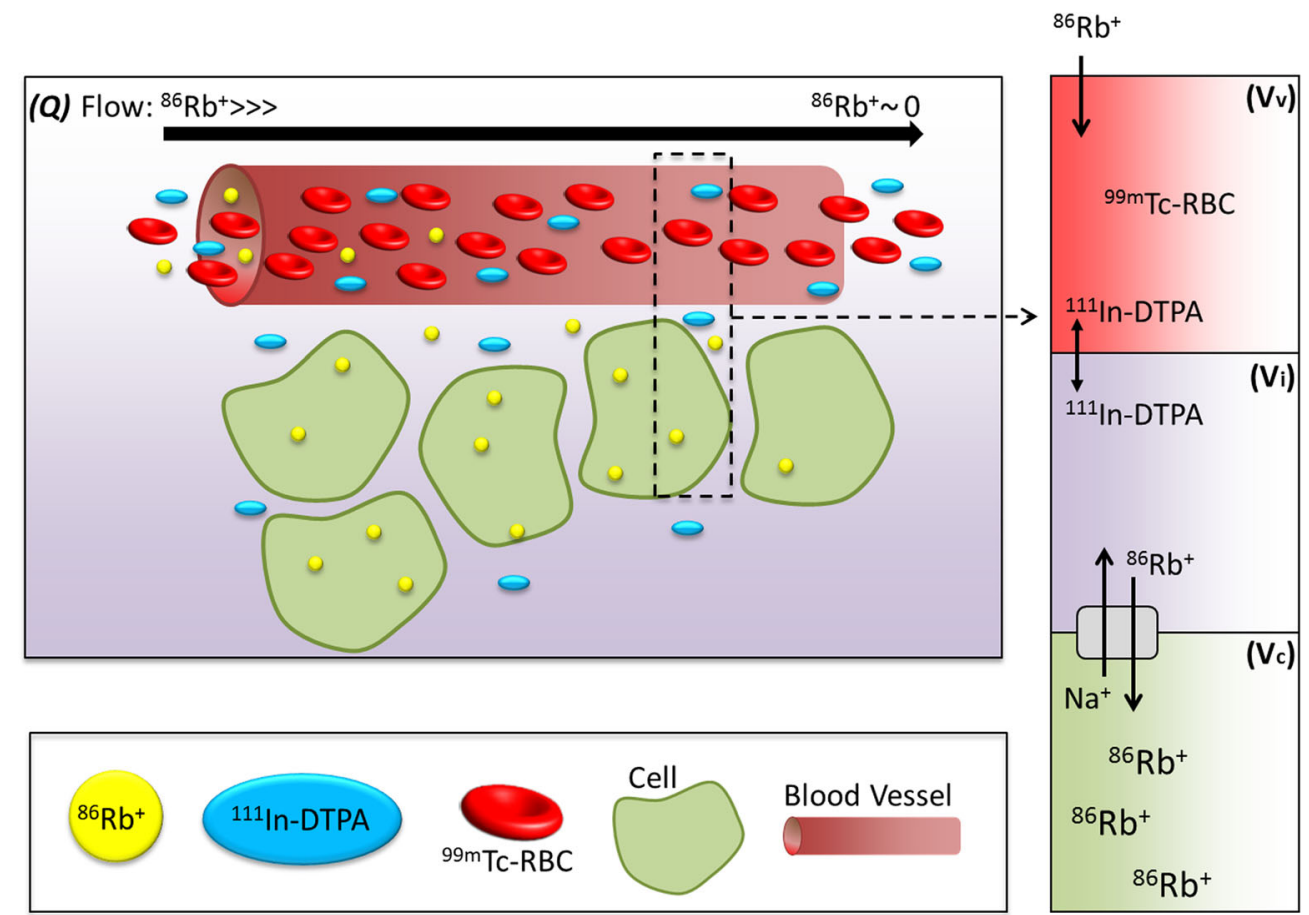

Fig. 1. Schematic of compartmental tissue measurements. Conceptual illustration of three physiological parameters-vascular volume $\left(V_{\mathrm{v}}\right)$, interstitial volume $\left(V_{\mathrm{i}}\right)$, and blood flow $(Q)$. Red blood cells (RBCs) labeled with ${ }^{99 \mathrm{~m}} \mathrm{Tc}$ are restricted to the vascular space $\left(V_{\mathrm{v}}\right)$. The intravenously infused extracellular marker, ${ }^{111}$ In-DTPA, reaches equilibrium between plasma and interstitial fluid $\left(V_{\mathrm{i}}\right)$. The intravenous bolus dose of the blood flow $(Q)$ probe ${ }^{86} \mathrm{Rb}^{+}$quickly extravasates and is sequestered into cells via sodium/potassium ion transporters

variability in these physiologic values by measuring $V_{\mathrm{v}}, V_{\mathrm{i}}$, and $Q$ in cynomolgus monkeys using standardized methods that we have also previously applied to rats [28] and mice [26].

\section{MATERIALS AND METHODS}

Ethical Approval. All procedures were conducted in accordance with the Animal Welfare Act, the Guide for the Care and Use of Laboratory Animals, the Office of Laboratory Animal Welfare, and the IACUC at the in-life study site. Care and housing were USDA regulatory compliant.

Animal Care. A total of eight drug-naïve cynomolgus monkeys (Chinese origin) ranging from 2 to 7 years of age and from 2 to $5 \mathrm{~kg}$ weight from Covance Research Products, Inc., (Alice, TX) or from a Covance stock colony were used. Tissues were harvested from six monkeys following euthanasia (three each for $V_{\mathrm{v}} / Q$ and $V_{\mathrm{i}}$ ), while two additional monkeys served as blood donors without requiring euthanasia. Animals were allowed to commingle during the 1-week acclimation period (prior to administration of radionuclides), but were housed individually in stainless steel cages during the <1-day test period. Certified Global Primate Diet No. 2055 (Harlan Teklad, Inc.) and fresh water (ad libitum) were provided and supplemented with appropriate fruits and cereals as treats. Cage enrichment devices were used for environmental and psychological enrichment. Environmental controls were set to maintain a temperature of 20 to $26^{\circ} \mathrm{C}$, a relative humidity of $50 \% \pm 20 \%$, and a 12-h light/12-h dark cycle.

Derivation of Total Blood Volumes. The total blood volume of each monkey was calculated from the total radioactive dose in counts per minute (CPM) of ${ }^{99 \mathrm{~m}} \mathrm{Tc}$ fortified blood and the radioactive $\left({ }^{99 \mathrm{~m}} \mathrm{Tc}\right)$ concentration in blood at time of euthanasia in CPM per microliter as follows:

Total blood volume $=\frac{\text { Total dose }\left(\mathrm{CPM}_{\mathrm{Tc}-99 \mathrm{~m}}\right)}{\frac{\mathrm{CPM}_{\mathrm{Tc}-99 \mathrm{~m}}}{\mu \mathrm{L} \text { blood }}}$

The same approach was used to calculate total blood volumes of rats and mice from our previously reported studies [21, 23-28], and blood volumes were normalized to body weight $(\mathrm{kg})$ for comparison across species.

Measurement of Organ-Level Vascular Volumes and Rates of Blood Flow. The vascular spaces of monkey tissues were measured using a previously reported indirect red blood cell (RBC) labeling/transfusion method [22] based on protocols used in both clinical blood pool imaging [31] and preclinical studies [32, 54, 55]. Using a dual radionuclide detection strategy, regional blood flow rates $(Q)$ in various organs and tissues were determined in the same animals by prompt euthanasia after intravenous bolus injection of ${ }^{86} \mathrm{Rb}$ chloride $\left({ }^{86} \mathrm{RbCl}\right)[32,42-45]$. The RBC labeling method relies on tin-mediated reduction of ${ }^{99 \mathrm{~m}} \mathrm{Tc}$ pertechnetate 
intracellularly so that it may bind to the beta chain of hemoglobin [30]. An appropriate number of animals were pre-screened to ensure donor blood compatibility, evident by a lack of antigen-antibody reaction resulting in clumping or hemagglutination in blood samples. TechneScan PYPтм (i.e., stannous pyrophosphate kits for preparation of ${ }^{99 \mathrm{~m}} \mathrm{Tc}$ pyrophosphate injection) were obtained from a radiopharmacy and used according to label instructions for the in vivo method of blood pool imaging with the appropriate human-to-monkey scaling based on relative body weight. Each reconstituted clinical kit vial of TechneScan PYPTM contains $4 \mathrm{mg}$ of tin chloride (three human doses) in $3 \mathrm{~mL}$. Two donor cynomolgus monkeys received bolus IV injections of stannous pyrophosphate. Approximately $30 \mathrm{~min}$ later, blood (approximately $3 \mathrm{~mL}$ ) was collected into tubes containing $\mathrm{K}_{2}$ EDTA anticoagulant and maintained at ambient temperature. Approximately $7 \mathrm{mCi}$ of ${ }^{99 \mathrm{~m}} \mathrm{Tc}$ pertechnetate saline solution (approximately $165 \mu \mathrm{L}$ ) was added to each $3 \mathrm{~mL}$ sample of blood. The fortified samples were gently inverted to mix and incubated with gentle rotation at ambient temperature for approximately $20 \mathrm{~min}$. Three study animals $(3.3-4.3 \mathrm{~kg})$ received a bolus IV injection of approximately $0.5 \mathrm{~mL}$ of ${ }^{99 \mathrm{~m}} \mathrm{Tc}$-fortified blood $(\sim 1 \mathrm{mCi})$ followed by $0.1 \mathrm{~mL}$ of ${ }^{86} \mathrm{Rb}$ chloride (PerkinElmer, $\sim 100 \mu \mathrm{Ci}$ ) approximately $30 \mathrm{~min}$ later. Approximately $1 \mathrm{~min}$ after the ${ }^{86} \mathrm{RbCl}$ dose, blood was collected into tubes containing $\mathrm{K}_{2}$ EDTA anticoagulant and placed on wet ice prior to subsampling and centrifugation to obtain plasma. Animals were euthanized within 2.5 to $3.5 \mathrm{~min}$ after the ${ }^{86} \mathrm{RbCl}$ dose via an overdose of sodium pentobarbital. Following blood collection, tissues were collected as described below for prompt radioanalysis of ${ }^{99 \mathrm{~m}} \mathrm{Tc}\left(140 \mathrm{keV}\right.$ gamma energy, $t_{1 / 2}$ $\sim 6 \mathrm{~h})$, followed by radioanalysis of ${ }^{86} \mathrm{Rb}(1774 \mathrm{keV}$ gamma energy, $t_{1 / 2} \sim 18.6$ days) subsequent to ${ }^{99} \mathrm{~m}$ Tc decay. $V_{\mathrm{v}}$ was calculated from ${ }^{99 \mathrm{~m}} \mathrm{Tc}$ counts as follows:

$V_{\mathrm{v}}\left(\frac{\mu \mathrm{L}}{\mathrm{g} \text { tissue }}\right)=\frac{\frac{\mathrm{CPM}_{\mathrm{Tc}-99 \mathrm{~m}}}{\mathrm{~g} \text { tissue }}}{\frac{\mathrm{CPM} \mathrm{Mc}_{\mathrm{Tc}-99 \mathrm{~m}}}{\mu \mathrm{L} \text { blood }}}$

By converting to milliliters per gram (i.e., $\left.V_{\mathrm{v}} / 1000\right)$, one can easily derive the fractional vascular volume $(\gamma)$, a unitless value if one assumes that blood and tissue have equal densities. Importantly, drug concentrations in tissues $\left(C_{\mathrm{t}}\right)$ may be corrected for circulating drug in blood based on $V_{\mathrm{v}}$ using the following equation, where $C_{\mathrm{b}}(\mu \mathrm{g} / \mu \mathrm{L})$ is the concentration of drug in whole blood:

$C_{\mathrm{t}, \text { blood corrected }}\left(\frac{\mu \mathrm{g}}{\mathrm{g} \text { tissue }}\right)=C_{\mathrm{t}, \text { total }}-V_{\mathrm{v}} \times C_{\mathrm{b}}$

Rates of blood flow $(Q)$ were calculated from ${ }^{86} \mathrm{Rb}$ counts where total cardiac outputs $\left(\mathrm{CO}_{\text {total }}\right)$ are $8000,74,000$, and $884,000 \mu \mathrm{L} / \mathrm{min}$ for mice, rats, and monkeys, respectively [52], as follows:
$Q\left(\frac{\mu \mathrm{L}}{\mathrm{g} \cdot \mathrm{min}}\right)=\frac{\frac{\mathrm{CPM}_{\mathrm{Rb}-86}}{\mathrm{~g} \text { tissue }} \times \mathrm{CO}_{\text {total }}}{\text { Total Dose }\left(\mathrm{CPM}_{\mathrm{Rb}-86}\right)}$

The cardiac output for the monkeys weighing $3.8 \mathrm{~kg}$ (884,000 $\mu \mathrm{L} / \mathrm{min}$ ) was derived by allometrically scaling (using an exponent of 0.75) [20] the value previously reported for monkeys weighing $5 \mathrm{~kg}[52,56]$. Values for 20 and $250 \mathrm{~g}$ mice and rats, respectively, were used without scaling.

Measurement of Organ-Level Interstitial Volumes. The interstitial spaces of monkey tissues were measured by continuous infusion of the extracellular marker, ${ }^{111}$ In-DTPA [38, 39]. ${ }^{111} \mathrm{In}$ DTPA (clinical grade, GE Healthcare) was administered $(\sim 3 \mathrm{mCi}$, 11-12 $\mathrm{mL})$ as an intravenous infusion over approximately $1 \mathrm{~h}$. Three animals (2.7-5.2 kg), previously acclimated to the procedure, were restrained in chairs throughout dose administration. Upon completion of the infusion, blood (at least $5 \mathrm{~mL}$, collected into a 6-mL vacutainer) was immediately (within 1 min after the end of infusion) collected into tubes containing $\mathrm{K}_{2}$ EDTA anticoagulant. Blood samples were placed on wet ice prior to subsampling and centrifugation to obtain plasma. Animals were euthanized within 1.5 min after the end of infusion via overdose of sodium pentobarbital anesthesia. Tissues were harvested as described below followed by radioanalysis for ${ }^{111}$ In (171 and $245 \mathrm{keV}$ gamma energies, $t_{1 / 2} \sim 2.8$ days). $V_{\mathrm{i}}$ was calculated from ${ }^{111} \mathrm{In}$ counts and $V_{\mathrm{v}}$ values (see below) as follows:

$V_{\mathrm{i}}\left(\frac{\mu \mathrm{L}}{\mathrm{g} \text { tissue }}\right)=\frac{\frac{\mathrm{CPM}_{\text {In }-111}}{\mathrm{~g} \text { tissue }}-\frac{\mathrm{CPM}_{\text {In }-111}}{\mu \mathrm{L} \text { blood }} \times V_{\mathrm{v}}\left(\frac{\mu \mathrm{L}}{\mathrm{g} \text { tissue }}\right)}{\frac{\mathrm{CPM}_{\text {In }-111}}{\mu \mathrm{L} \text { plasma }}}$

The above equation assumes that ${ }^{111}$ In-DTPA is in steady-state equilibrium between plasma and tissue interstitial fluid at time of euthanasia and tissue harvest. Importantly, for drugs with little to no cell partitioning (e.g., antibodies), conversion of blood-corrected whole tissue drug concentrations $\left(C_{\mathrm{t} \text {,blood corrected }}\right)$ to interstitial concentrations $\left(C_{\mathrm{i}}\right)$ may be achieved using the following equation:

$C_{\mathrm{i}}\left(\frac{\mu \mathrm{g}}{\mu \mathrm{L}}\right)=C_{\mathrm{t}, \text { blood corrected }} / V_{\mathrm{i}}$

Blood-Brain Barrier Permeability. Blood-corrected brain levels of ${ }^{111}$ In-DTPA, normalized to plasma levels, were compared across species as indicators of blood-brain barrier permeability. The calculation is analogous to the equation for $V_{\mathrm{i}}$ as described above but is designated as a brain partitioning coefficient $\left(K_{\mathrm{p}}\right)$ to highlight the lack of physiological relevance to brain $V_{\mathrm{i}}$.

Tissue Handling and Analysis. Harvested tissues included brain, colon (without contents), eyes, fat 
(subcutaneous), heart, ileum (without contents), kidneys, liver, lungs, muscle (from the thigh), skin (dorsal), and spleen. Brain, heart, kidneys, and lungs were collected in entirety, weighed, divided into pieces, supplemented with reverse osmosis water (approximately twice the sample weight), homogenized in a blender, and divided into duplicate aliquots for analysis by solid scintillation (i.e., gamma) counting. Colon and ileum were collected in entirety, emptied of their contents, weighed, and divided into duplicate representative samples ( $1 \mathrm{~g}$ each). Duplicate representative samples of fat, muscle, and skin were collected. Colon, eyes, fat, ileum, muscle, and skin samples were not homogenized; instead, samples were lightly rinsed and blotted dry, weighed, and placed on wet ice prior to transfer for analysis by solid scintillation counting. Blood was mixed and duplicate weighed aliquots were analyzed by solid scintillation counting. Samples were analyzed for at least $1 \mathrm{~min}$ or $1,000,000$ counts. As applicable, one complete set of samples (one aliquot per sample) was counted; the second set was then analyzed.

Allometric Analysis. To evaluate the scalability of measured parameters across different species, we conducted an allometric analysis. Tissue weight-normalized values were multiplied by their respective organ weights (Table S1) in order to express measured values on a per-organ basis ( $Q$ in $\mu \mathrm{L} / \mathrm{min}, V_{\mathrm{v}}$ in $\mu \mathrm{L}, V_{\mathrm{i}}$ in $\left.\mu \mathrm{L}\right)$. Estimated tissue-specific values were related to total animal body weights (BW) by the equation:

$Y=A \times \mathrm{BW}^{b}$

where $Y$ corresponds to $V_{\mathrm{v}}, V_{\mathrm{i}}$, and $Q$ and $\mathrm{BW}$ is the total body weight for each animal. $A$ and $b$, the allometric coefficient and exponent, are fitted parameters (Table S2). A value of $b=1$ suggests that the parameter $Y$ scales proportionally with $\mathrm{BW}$ and $b$ values lower or greater than 1 suggests that $Y$ scales less or more than BW proportionally, respectively. Extrapolation of the linear regression lines to $70 \mathrm{~kg}$ was used to estimate values in human, which were subsequently normalized using human organ weights from the literature [52].

Sensitivity Analysis. We used a previously published PBPK model [10], which we scaled from mouse to cynomolgus monkey (Table S3), to evaluate the impact of uncertainty in $V_{\mathrm{v}}, V_{\mathrm{i}}$, and $Q$ on simulated total uptake of a $150-\mathrm{kDa}$ monoclonal antibody in selected fast and slow perfused tissues. Using the scaled cyno model, concentration-time curves were simulated using $V_{\mathrm{v}}, V_{\mathrm{i}}$, and $Q$ values measured here and those compiled by Shah and Betts [13]. The area under each simulated \% injected dose versus time curve from 0 to 7 days $\left(\mathrm{AUC}_{7}\right)$ was calculated and compared.

\section{RESULTS}

Total Blood Volumes. Measured whole-body blood volumes are shown in Table I. Total BV values $(\mathrm{mL})$ were $181 \pm$
24 in monkey and $10.2 \pm 0.5$ in rat and ranged from $1.3 \pm 0.1$ to $2.1 \pm 0.1$ in mice. Weight-normalized $\mathrm{BV}$ values $(\mathrm{mL} / \mathrm{kg})$ were $47.7 \pm 0.8$ in cynomolgus monkeys and $48 \pm 2$ in Sprague-Dawley rats and ranged from $59 \pm 5$ for C57BL-6 to $109 \pm 4$ for C.B-17 SCID beige mice. Higher weightnormalized $\mathrm{BVs}$ were measured in immunocompromised strains (108 in nude and 109 in SCID) relative to immunocompetent strains (ranging from 59 to 78) despite a similar body weight range.

Vascular Volumes. $V_{\mathrm{v}}$ in monkey tissues, derived from ${ }^{99} \mathrm{~m}$ Tc labeling of red blood cells and expressed in microliters of blood per gram $(\mu \mathrm{L} / \mathrm{g})$ of tissue, are presented in the first column of Table II. $V_{\mathrm{v}}$ in muscle was roughly consistent across cynomolgus monkeys and our previously measured values in other species (Table II, columns 2-8), ranging overall from $5.4 \pm 2.0$ to $9 \pm 2$ (both values in mice). Muscle $V_{\mathrm{v}}$ values were $7 \pm 1,7 \pm 1$, and $5.5 \pm 1.1$ for cynomolgus monkeys, rat, and DBA/2 mice, respectively. Monkey tissue $V_{\mathrm{v}}$ values ranged from $4 \pm 1$ in eyes to $188 \pm 22$ in kidneys. One notable exception was lung, for which the $V_{\mathrm{v}}$ value in rats $(538 \pm 69)$ was significantly higher than that in monkeys $(126 \pm 29)$ and mice (ranging from $125 \pm 17$ to $214 \pm 78$ ). While the high rat lung $V_{\mathrm{v}}$ was reproduced in a second study, we suspect that blood pooling during euthanasia and harvest exaggerated the value as the mean rat lung weights were higher than expected.

Interstitial Volumes. Measured tissue-level $V_{\mathrm{i}}$ in cynomolgus monkeys, derived from ${ }^{111}$ In-DTPA levels and expressed in microliters of interstitial fluid per gram $(\mu \mathrm{L} / \mathrm{g})$ of tissue, are presented in the first column of Table III. It is critical to note that ${ }^{111}$ In-DTPA does not provide physiologically meaningful measurements of $V_{\mathrm{i}}$ in kidney and brain/eye due to probe clearance and lack of blood-brain/ ocular-barrier permeability, respectively. A remarkably good agreement in $V_{\mathrm{i}}$ on a per-gram-tissue basis was observed across most monkey tissues analyzed here and previously analyzed rodent tissues. For instance, measured $V_{\mathrm{i}}$ in muscle were fairly consistent across cynomolgus monkeys and our previously measured values in other species (Table III, columns 2-7), ranging overall from $48 \pm 8$ in female SCID beige mice to $108 \pm 18$ in monkeys. Muscle $V_{\mathrm{i}}$ values in immunocompetent mice (ranging from $92 \pm 27$ to $93 \pm 20$ ) and rats $(93 \pm 18)$ were similar to the value in monkeys. Monkey tissue $V_{\mathrm{i}}$ values ranged from $71 \pm 40$ in spleen to $268 \pm 50$ in skin.

Rates of Blood Flow. Measured tissue-level rates of blood flow $(Q)$ in cynomolgus monkeys derived from ${ }^{86} \mathrm{RbCl}$ expressed in microliters of blood per gram of tissue per minute $(\mu \mathrm{L} / \mathrm{g} / \mathrm{min})$ are presented in the first column of Table IV. Importantly, ${ }^{86} \mathrm{RbCl}$ cannot freely cross the bloodbrain and blood-ocular barriers so values for brain and eyes are not shown [50]. It should also be noted that ${ }^{86} \mathrm{RbCl}$ may somewhat exaggerate $Q$ in heart due to cardiac sequestration of $\mathrm{Rb}^{+}$through $\mathrm{K}^{+}$channels and $\mathrm{Na}^{+} / \mathrm{K}^{+}$-ATPase pumps [57]. $Q$ in muscle for monkeys $(231 \pm 54)$ was in good agreement with previously measured rodent values (Table IV, columns $2-7$ ), including $190 \pm 38$ in rats and ranging from $186 \pm 47$ to $300 \pm 34$ in mice. Monkey tissue $Q$ values ranged from $93 \pm 23$ 
Table I. Summary of Species/Strains in Which $V_{\mathrm{v}}, V_{\mathrm{i}}$, and $Q$ Were Measured in Previous and Current Studies with Body Weights and Measured Whole-body Blood Volumes (BV)

\begin{tabular}{|c|c|c|c|c|c|c|c|c|}
\hline Species & Strain/origin & Sex & Immunocompetent & Number & $\begin{array}{l}\text { Body } \\
\text { weight } \\
\text { (g) }\end{array}$ & $\begin{array}{l}\text { Total } \\
\text { BV }(\mathrm{mL})\end{array}$ & $\begin{array}{l}\text { Weight-normalized } \\
\text { BV }(\mathrm{mL} / \mathrm{kg})\end{array}$ & Data source \\
\hline $\begin{array}{l}\text { Homo sapiens } \\
\quad \text { (human) }\end{array}$ & Global average & $\mathrm{M} / \mathrm{F}$ & Yes & $\mathrm{n} / \mathrm{a}$ & 70,000 & 5200 & 74 & {$[50]$} \\
\hline $\begin{array}{l}\text { Macaca fascicularis } \\
\text { (cynomolgus monkey) }\end{array}$ & Chinese origin & M & Yes & 3 & $3800 \pm 400$ & $181 \pm 24$ & $47.7 \pm 0.8$ & Current study \\
\hline $\begin{array}{l}\text { Rattus } \\
\quad \text { norvegicus (rat) }\end{array}$ & Sprague-Dawley & $\mathrm{F}$ & Yes & 5 & $213 \pm 4$ & $10.2 \pm 0.5$ & $48 \pm 2$ & {$[28]$} \\
\hline $\begin{array}{l}\text { Mus musculus } \\
\text { (mouse) }\end{array}$ & $\mathrm{DBA} / 2$ & $\mathrm{~F}$ & Yes & 5 & $19 \pm 1$ & $1.5 \pm 0.1$ & $78 \pm 4$ & {$[26,28]$} \\
\hline $\begin{array}{l}\text { Mus musculus } \\
\text { (mouse) }\end{array}$ & C57BL-6 & $\mathrm{F}$ & Yes & $\begin{array}{l}4 \\
4\end{array}$ & $\begin{array}{l}21.0 \pm 0.6 \\
22 \pm 4^{\mathrm{a}}\end{array}$ & $\begin{array}{l}\mathrm{n} / \mathrm{a} \\
1.3 \pm 0.1\end{array}$ & $\begin{array}{l}\mathrm{n} / \mathrm{a} \\
59 \pm 5\end{array}$ & [26-28] \\
\hline $\begin{array}{l}\text { Mus musculus } \\
\text { (mouse) }\end{array}$ & $\begin{array}{l}\text { B6SJL-Tg } \\
\quad(\text { SOD1) } 2 \mathrm{Gur} / \mathrm{J}\end{array}$ & $\mathrm{F}$ & Yes & 5 & $23 \pm 3$ & $1.6 \pm 0.1$ & $68 \pm 7$ & {$[23]$} \\
\hline Mus musculus (mouse) & Beige nude & $\mathrm{F}$ & No & 5 & $18.8 \pm 0.6$ & $2.0 \pm 0.1$ & $108 \pm 5$ & {$[21]$} \\
\hline Mus musculus (mouse) & C.B-17 SCID.bg & $\mathrm{F}$ & No & 5 & $20 \pm 2$ & $2.2 \pm 0.1$ & $109 \pm 4$ & [24] \\
\hline Mus musculus (mouse) & C.B-17 SCID.bg & M & No & 4 & $26 \pm 1$ & $\mathrm{n} / \mathrm{a}$ & $\mathrm{n} / \mathrm{a}$ & {$[25]$} \\
\hline
\end{tabular}

$M$, male; $F$, female; $n / a$, not available

${ }^{a}$ Measured in two separate studies

in skin to $3365 \pm 961$ in kidneys. The $Q$ value in monkey spleen $(471 \pm 99)$ was comparable to previously measured values in rats $(572 \pm 134)$ but generally higher than previously measured values in mice (ranging from $124 \pm 51$ to $326 \pm 43$ ).

Blood-Brain Barrier Permeability. Brain $K_{\mathrm{p}}$ values measured in monkeys $(0.003 \pm 0.001)$ were significantly lower than previously measured values in rats $(0.019 \pm 0.007)$ and mice (ranging from $0.016 \pm 0.007$ to $0.035 \pm 0.012$ ) (Fig. 2).

Allometric Analysis. Results from the allometric analysis are shown in Fig. 3. Qualitatively, the observed data is consistent with the allometric relationship, where values of $V_{\mathrm{v}}(\mu \mathrm{L}), V_{\mathrm{i}}(\mu \mathrm{L})$, and $Q(\mu \mathrm{L} / \mathrm{min})$ across species are largely dependent on BW. Parameter values for human are obtained by extrapolation of the regression lines to $70 \mathrm{~kg}$ body weight (Table V). Human parameters were all generally lower than the corresponding monkey parameters on a tissue weightnormalized basis. For instance, $V_{\mathrm{v}}(\mu \mathrm{L} / \mathrm{g}), V_{\mathrm{i}}(\mu \mathrm{L} / \mathrm{g})$, and $Q$ $(\mu \mathrm{L} / \mathrm{g} / \mathrm{min}$ ) were 59,87 , and 173 in human lung compared to our measured values of 126, 247, and 570 in monkey lung. Most exponents were between $\sim 0.9$ and 1 . An exception was $V_{\mathrm{i}}$ in liver which was $0.8, Q$ in kidney and spleen which were $\sim 0.85$, and $V_{\mathrm{v}}$ in kidney which was 0.87 (Table S2). The allometric plots with $95 \%$ confidence intervals are provided in Fig. S1.

Sensitivity Analysis. The sensitivity analysis compares the impact of various values (our measured values versus previously assembled literature values [13]) of $V_{\mathrm{v}}, V_{\mathrm{i}}$, and $Q$ on $\mathrm{AUC}_{7}$ of an antibody in muscle and liver, in cynomolgus monkeys (Table S3). AUC 7 values of simulated \% ID versus time curves in both tissues are most sensitive to changes in $V_{\mathrm{v}}$, where for muscle a $131 \%$ increase in $\mathrm{AUC}_{7}$ results from using the literature value of $V_{\mathrm{v}}(40 \mu \mathrm{L} / \mathrm{g})$ versus the value estimated here $(7 \mu \mathrm{L} / \mathrm{g})$ and for liver a $55 \%$ increase in $\mathrm{AUC}_{7}$ results from using the literature value of $V_{\mathrm{v}}(155 \mu \mathrm{L} / \mathrm{g})$ versus the value estimated here $(92 \mu \mathrm{L} / \mathrm{g})$. The impact of $V_{\mathrm{i}}$ on $\mathrm{AUC}_{7}$ is less pronounced, with almost no increase in $\mathrm{AUC}_{7}$ for muscle when using the literature value $(130 \mu \mathrm{L} / \mathrm{g})$ versus the value estimated here $(108 \mu \mathrm{L} / \mathrm{g})$ and a modest increase in liver (which has much higher vascular permeability) of $18 \%$ when using the literature value $(200 \mu \mathrm{L} / \mathrm{g})$ versus the value estimated here $(100 \mu \mathrm{L} / \mathrm{g})$. For large molecular weight compounds such as the $150-\mathrm{kDa}$ antibody considered here, extravasation from the vascular to interstitial space is the rate-limiting step for tissue uptake; therefore, $\mathrm{AUC}_{7}$ is almost completely insensitive to the range of $Q$ values evaluated for muscle and liver $(37-416 \mu \mathrm{L} / \mathrm{min} / \mathrm{g})$, consistent with previous findings [16, 17]. Although not evaluated here, one would expect small molecule tissue uptake to be sensitive to $Q$ [58]. The sensitivity analyses discussed here and in previous works $[16,17]$ are, strictly speaking, valid only for each respective model/parameter combination. As good practice, parameter sensitivity analysis should be re-evaluated each time the model is fitted to a new biodistribution data set.

\section{DISCUSSION}

Prior to this study, a relatively limited amount of organlevel physiological data in primates was available; furthermore, primate and rodent data were often acquired by different methods [18]. Organ-level values used by PBPK modelers, exemplified by a recent example [13], are usually obtained from various literature sources that include compilations of previously measured and assumed nominal values. In many cases, citations for physiological parameter values used in modeling papers refer to earlier modeling or review papers, such that ascertaining the original source and, importantly, the associated in vivo measurement methods (if 
Table II. Measured Organ-Level Vascular Volumes $\left(V_{\mathrm{v}}\right)$ in Various Laboratory Animal Species. All Values Were Measured by the Same ${ }^{99 \mathrm{~m}} \mathrm{Tc}$ Red Blood Cell Labeling Method. Each Study Is $N=5$ Animals per Group Unless Otherwise Noted. Values in Brackets Indicate Data from a Second Independent Study. Data from Individual Animals, for Cynomolgus Monkey Only, Are Available in Supplementary Table S7

\begin{tabular}{|c|c|c|c|c|c|c|c|c|}
\hline Tissue & $\begin{array}{l}\text { Monkey } \\
\text { Cynomolgus } \\
\text { Current } \\
\text { study, } \\
N=3\end{array}$ & $\begin{array}{l}\text { Rat } \\
\text { Sprague-Dawley } \\
\text { [28] } \\
\text { Study } 1 \\
\text { [study 2], }\end{array}$ & $\begin{array}{l}\text { Mouse } \\
\mathrm{DBA} / 2 \\
{[28,26]}\end{array}$ & $\begin{array}{l}\text { Mouse } \\
\text { C57/B16 } \\
\text { Study 1 [28, 26] } \\
\text { [study 2] [27] } \\
N=4, \\
\text { both studies }\end{array}$ & $\begin{array}{l}\text { Mouse } \\
\text { B6SJL-Tg } \\
\text { (SOD1) } \\
\text { 2Gur/J [23] }\end{array}$ & $\begin{array}{l}\text { Mouse } \\
\text { beige } \\
\text { nude } \\
\text { XID } \\
{[22,21]}\end{array}$ & $\begin{array}{l}\text { Mouse } \\
\text { C.B-17 } \\
\text { SCID } \\
\text { beige } \\
\text { (female) [24] }\end{array}$ & $\begin{array}{l}\text { Mouse } \\
\text { C.B-17 SCID } \\
\text { beige (male) [25] } \\
(N=4)\end{array}$ \\
\hline SM intestine & $16 \pm 2$ & $\begin{array}{l}26 \pm 8 \\
{[22 \pm 3]}\end{array}$ & $16.4 \pm 0.4$ & $\begin{array}{l}6 \pm 1 \\
{[6.8 \pm 0.4]}\end{array}$ & $13 \pm 9$ & $8 \pm 2$ & $7 \pm 3$ & $10 \pm 5$ \\
\hline LG intestine & $27 \pm 7$ & $\begin{array}{l}20 \pm 4 \\
{[19 \pm 5]}\end{array}$ & $11 \pm 5$ & $5.3 \pm 0.6$ & $\mathrm{n} / \mathrm{a}$ & $\mathrm{n} / \mathrm{a}$ & $\mathrm{n} / \mathrm{a}$ & $13 \pm 3$ \\
\hline Lung & $126 \pm 29$ & $\begin{array}{l}538 \pm 69 \\
{[605 \pm 84]}\end{array}$ & $160 \pm 27$ & $\begin{array}{l}146 \pm 13 \\
{[125 \pm 17]}\end{array}$ & $126 \pm 26$ & $192 \pm 64$ & $214 \pm 78$ & $207 \pm 101$ \\
\hline Liver & $92 \pm 8$ & $\begin{array}{l}124 \pm 75 \\
{[92 \pm 18]}\end{array}$ & $45 \pm 13$ & $\begin{array}{l}41 \pm 10 \\
{[44 \pm 4]}\end{array}$ & $38 \pm 4$ & $42 \pm 8$ & $55 \pm 11$ & $55 \pm 10$ \\
\hline Kidneys & $188 \pm 22$ & $\begin{array}{l}190 \pm 20 \\
{[186 \pm 21]}\end{array}$ & $110 \pm 19$ & $\begin{array}{l}89 \pm 10 \\
{[117 \pm 20]}\end{array}$ & $121 \pm 10$ & $77 \pm 7$ & $108 \pm 28$ & $111 \pm 24$ \\
\hline Heart & $73 \pm 10$ & $\begin{array}{l}82 \pm 24 \\
{[222 \pm 58]}\end{array}$ & $96 \pm 41$ & $\begin{array}{l}40 \pm 10 \\
{[38 \pm 4]}\end{array}$ & $53 \pm 18$ & $30 \pm 7$ & $49 \pm 9$ & $42 \pm 22$ \\
\hline Spleen & $169 \pm 41$ & $\begin{array}{l}261 \pm 120 \\
{[440 \pm 66]}\end{array}$ & $76 \pm 16$ & $\begin{array}{l}92 \pm 14 \\
{[94 \pm 5]}\end{array}$ & $87 \pm 20$ & $121 \pm 29$ & $117 \pm 36$ & $153 \pm 45$ \\
\hline Muscle & $7 \pm 1$ & $\begin{array}{l}7 \pm 1 \\
{[9 \pm 4]}\end{array}$ & $5.5 \pm 1.1$ & $\begin{array}{l}5.9 \pm 0.9 \\
{[5.8 \pm 0.9]}\end{array}$ & $6 \pm 1$ & $9 \pm 2$ & $5.4 \pm 2.0$ & $9 \pm 3$ \\
\hline Fat & $25 \pm 19$ & $\begin{array}{l}14 \pm 2 \\
{[12 \pm 8]}\end{array}$ & $11 \pm 4$ & $6 \pm 3$ & $\mathrm{n} / \mathrm{a}$ & $14 \pm 4$ & $9 \pm 4$ & $\mathrm{n} / \mathrm{a}$ \\
\hline Brain & $8 \pm 1$ & $\begin{array}{l}9 \pm 1 \\
{[10 \pm 2]}\end{array}$ & $10 \pm 1.3$ & $\begin{array}{l}8 \pm 1 \\
{[9 \pm 1]}\end{array}$ & $7 \pm 1$ & $11 \pm 2$ & $11 \pm 3$ & $\mathrm{n} / \mathrm{a}$ \\
\hline Skin & $13 \pm 2$ & $\begin{array}{l}13 \pm 3 \\
{[11 \pm 2]}\end{array}$ & $5.3 \pm 2.6$ & $\begin{array}{l}14 \pm 9 \\
{[8 \pm 1]}\end{array}$ & $7 \pm 1$ & $\mathrm{n} / \mathrm{a}$ & $8 \pm 7$ & $7 \pm 2$ \\
\hline Stomach & $\mathrm{n} / \mathrm{a}$ & $\begin{array}{l}19 \pm 4 \\
{[23 \pm 5]}\end{array}$ & $11 \pm 1.6$ & $9 \pm 2$ & $\mathrm{n} / \mathrm{a}$ & $\mathrm{n} / \mathrm{a}$ & $\mathrm{n} / \mathrm{a}$ & $\mathrm{n} / \mathrm{a}$ \\
\hline Thymus & $\mathrm{n} / \mathrm{a}$ & $\begin{array}{l}18 \pm 4 \\
{[17 \pm 4]}\end{array}$ & $140 \pm 60$ & $14 \pm 8$ & $\mathrm{n} / \mathrm{a}$ & $\mathrm{n} / \mathrm{a}$ & $\mathrm{n} / \mathrm{a}$ & $\mathrm{n} / \mathrm{a}$ \\
\hline Pancreas & $\mathrm{n} / \mathrm{a}$ & $\begin{array}{l}30 \pm 4 \\
{[30 \pm 6]}\end{array}$ & $15 \pm 14$ & $8 \pm 2$ & $\mathrm{n} / \mathrm{a}$ & $\mathrm{n} / \mathrm{a}$ & $\mathrm{n} / \mathrm{a}$ & $\mathrm{n} / \mathrm{a}$ \\
\hline Lymph node & $\mathrm{n} / \mathrm{a}$ & $\begin{array}{l}25 \pm 9 \\
{[6 \pm 8]}\end{array}$ & $17 \pm 5.5$ & $5.2 \pm 0.9$ & $\mathrm{n} / \mathrm{a}$ & $\mathrm{n} / \mathrm{a}$ & $\mathrm{n} / \mathrm{a}$ & $\mathrm{n} / \mathrm{a}$ \\
\hline Ovaries & $\mathrm{n} / \mathrm{a}$ & $\begin{array}{l}60 \pm 24 \\
{[125 \pm 86]}\end{array}$ & $\mathrm{n} / \mathrm{a}$ & $\mathrm{n} / \mathrm{a}$ & $\mathrm{n} / \mathrm{a}$ & $\mathrm{n} / \mathrm{a}$ & $\mathrm{n} / \mathrm{a}$ & $\mathrm{n} / \mathrm{a}$ \\
\hline Eyes & $4 \pm 1$ & $\mathrm{n} / \mathrm{a}$ & $\mathrm{n} / \mathrm{a}$ & $\mathrm{n} / \mathrm{a}$ & $\mathrm{n} / \mathrm{a}$ & $\mathrm{n} / \mathrm{a}$ & $\mathrm{n} / \mathrm{a}$ & $\mathrm{n} / \mathrm{a}$ \\
\hline
\end{tabular}

$S M$, small; $L G$, large; $n / a$, not available

any) is challenging. Our experimental strategy aimed to measure three critical parameters $-V_{\mathrm{v}}, V_{\mathrm{i}}$, and $Q$-in cynomolgus monkeys using protocols as consistent as possible with those we previously used in rodents [28]. This approach facilitates direct comparison of parameters, estimated using the same methodology, across three species-mice, rats, and monkeys - commonly used in translational pharmacology and drug development. Since our measurements were performed in cynomolgus monkeys of Chinese origin, it should be noted that parameters may vary across other monkey populations including other cynomolgus populations (e.g., Mauritian). Furthermore, the possibility that transport and other experimental stresses may have influenced our results cannot be dismissed; however, we included an acclimation period, commingling when feasible, treats, and other elements in our study design in order to minimize experimental stress as much as possible $[59,60]$.

With some important exceptions, our results measured in monkeys were consistent with our previous results obtained in mice and rats, where many of the measured tissue-specific body weight-normalized parameter values were largely similar across species (Tables II, III, IV). In general, similar values were measured for poorly perfused tissues like muscle while greater interspecies variability was observed for more highly perfused organs (e.g., heart, lung, liver). Furthermore, most of the $V_{\mathrm{v}}, V_{\mathrm{i}}$, and $Q$ values observed in this study are in reasonably good agreement with values that have been assembled by Shah and Betts for PBPK modeling [13]; however, there are certain exceptions worth noting. For instance, sizeable differences were observed between values 
Table III. Measured Organ-Level Interstitial Volumes $\left(V_{\mathrm{i}}\right)$ in Various Laboratory Animal Species. All Values Were Measured by the Same

${ }^{111}$ In-DTPA Probe Method. Each Study Is $N=5$ Animals per Group Unless Otherwise Noted. Data From Individual Animals, for Cynomolgus Monkey Only, Are Available in Supplementary Table S7

\begin{tabular}{|c|c|c|c|c|c|c|c|}
\hline Tissue & $\begin{array}{l}\text { Monkey } \\
\text { Cynomolgus } \\
\text { (current study) }(N=3)\end{array}$ & $\begin{array}{l}\text { Rat } \\
\text { Sprague-Dawley [28] }\end{array}$ & $\begin{array}{l}\text { Mouse } \\
\text { DBA/2 } \\
{[28,26](N=4)}\end{array}$ & $\begin{array}{l}\text { Mouse } \\
\text { C57/B16 } \\
{[28,26]}\end{array}$ & $\begin{array}{l}\text { Mouse } \\
\text { beige nude } \\
\text { XID [21] }\end{array}$ & $\begin{array}{l}\text { Mouse } \\
\text { C.B-17 } \\
\text { SCID beige } \\
\text { (female) }[24]\end{array}$ & $\begin{array}{l}\text { Mouse } \\
\text { C.B-17 SCID } \\
\text { beige (male) [25] }\end{array}$ \\
\hline SM intestine & $140 \pm 15$ & $163 \pm 43$ & $218 \pm 129$ & $116 \pm 33$ & $121 \pm 62$ & $112 \pm 47$ & $157 \pm 48$ \\
\hline LG intestine & $81 \pm 11$ & $248 \pm 69$ & $223 \pm 87$ & $158 \pm 37$ & $\mathrm{n} / \mathrm{a}$ & $\mathrm{n} / \mathrm{a}$ & $150 \pm 21$ \\
\hline Lung & $247 \pm 24$ & $157 \pm 90$ & $208 \pm 20$ & $206 \pm 69$ & $173 \pm 71$ & $210 \pm 62$ & $179 \pm 32$ \\
\hline Liver & $100 \pm 29$ & $187 \pm 82$ & $86 \pm 18$ & $148 \pm 48$ & $90 \pm 15$ & $72 \pm 9$ & $92 \pm 25$ \\
\hline Heart & $148 \pm 7$ & $105 \pm 54$ & $115 \pm 25$ & $143 \pm 48$ & $158 \pm 67$ & $184 \pm 92$ & $150 \pm 20$ \\
\hline Spleen & $71 \pm 40$ & $43 \pm 27$ & $24 \pm 4$ & $22 \pm 25$ & $25 \pm 10$ & $\mathrm{n} / \mathrm{a}$ & $20 \pm 7$ \\
\hline Muscle & $108 \pm 18$ & $93 \pm 18$ & $92 \pm 27$ & $93 \pm 20$ & $83 \pm 41$ & $48 \pm 8$ & $55 \pm 18$ \\
\hline Fat & $188 \pm 45$ & $57 \pm 25$ & $462 \pm 379$ & $97 \pm 36$ & $346 \pm 259$ & $49 \pm 12$ & $115 \pm 80$ \\
\hline Skin & $268 \pm 50$ & $709 \pm 139$ & $366 \pm 78$ & $452 \pm 126$ & $\mathrm{n} / \mathrm{a}$ & $259 \pm 81$ & $\mathrm{n} / \mathrm{a}$ \\
\hline Stomach & $\mathrm{n} / \mathrm{a}$ & $240 \pm 60$ & $210 \pm 99$ & $177 \pm 41$ & $\mathrm{n} / \mathrm{a}$ & $\mathrm{n} / \mathrm{a}$ & $\mathrm{n} / \mathrm{a}$ \\
\hline Thymus & $\mathrm{n} / \mathrm{a}$ & $197 \pm 53$ & $162 \pm 114$ & $204 \pm 89$ & $\mathrm{n} / \mathrm{a}$ & $\mathrm{n} / \mathrm{a}$ & $\mathrm{n} / \mathrm{a}$ \\
\hline Pancreas & $\mathrm{n} / \mathrm{a}$ & $120 \pm 63$ & $93 \pm 38$ & $70 \pm 31$ & $\mathrm{n} / \mathrm{a}$ & $\mathrm{n} / \mathrm{a}$ & $\mathrm{n} / \mathrm{a}$ \\
\hline Lymph node & $\mathrm{n} / \mathrm{a}$ & $178 \pm 49$ & $390 \pm 178$ & $153 \pm 117$ & $\mathrm{n} / \mathrm{a}$ & $\mathrm{n} / \mathrm{a}$ & $\mathrm{n} / \mathrm{a}$ \\
\hline Ovaries & $\mathrm{n} / \mathrm{a}$ & $111 \pm 24$ & $\mathrm{n} / \mathrm{a}$ & $\mathrm{n} / \mathrm{a}$ & $\mathrm{n} / \mathrm{a}$ & $\mathrm{n} / \mathrm{a}$ & $\mathrm{n} / \mathrm{a}$ \\
\hline
\end{tabular}

$S M$, small; $L G$, large; $n / a$, not available

reported by Shah and Betts [13] and those measured in this study for $V_{\mathrm{v}}$ in muscle, brain, and skin (our values lower in all three species); $Q$ in muscle and adipose (our values higher in monkey); and $Q$ in heart, thymus, and spleen (our values lower in mice and rats).

Our tissue-level $V_{\mathrm{v}}(\mu \mathrm{L} / \mathrm{g})$ values measured here in monkey and previously in mice and rats [28] were mostly consistent across these species (Table II). We are aware of only one publication that reports tissue-level $V_{\mathrm{v}}$ measurements in non-human primates; our cynomolgus monkey values differ greatly from the reported rhesus monkey values (our values are all lower, some by an order of magnitude) whose method of measurement could not be ascertained [12]. Lung $V_{\mathrm{v}}$ in monkeys agreed well with our values in mice but was significantly lower than those in rats (Table II). Our murine muscle $V_{\mathrm{v}}$ ranged from 5 to $7 \mu \mathrm{L} / \mathrm{g}$, consistent with previous reports of $\sim 5$ to $8 \mu \mathrm{L} / \mathrm{g}$ measured by ${ }^{51} \mathrm{Cr}$-labeled RBCs in murine leg muscle [38, 39]. Generally good agreement was also noted between the measured rat $V_{\mathrm{v}}$ values that we observed and those reported by Khor et al., (measured by ${ }^{51} \mathrm{Cr}$-labeled $\mathrm{RBCs}$ ) in intestine, stomach, brain, muscle, kidney, liver, lung, and spleen (but with poor agreement in lung) [61]. Our measured brain $V_{\mathrm{v}}$ values in rats $(9 \pm 1)$ and mice $(8-11 \mu \mathrm{L} / \mathrm{g})$ agree well with previously published values measured by ${ }^{14} \mathrm{C}$-labeled sucrose in rats $(13 \pm 3)$ [62] and by ${ }^{3} \mathrm{H}$-labeled inulin in mice (9.4) [63]. Our measured rat $V_{\mathrm{v}}$ values $(\mu \mathrm{L} / \mathrm{g})$ in skin $(13 \pm 3)$, muscle $(7 \pm 1)$, lung (538 \pm 69$)$, and kidney (184 \pm 18$)$ agreed reasonably well, with the exception of lung, with values previously measured by ${ }^{51}$ Cr-labeled RBCs $(6.7,6.5,218$, and 183 , respectively) [64]. However, in comparison to the values assembled by Shah and Betts [13], our measured $V_{\mathrm{v}}$ 's are consistently lower in muscle and skin and higher in lung (except mouse) and kidney (Table S4) across all species considered here. These disagreements may reflect the fact that $V_{\mathrm{v}}$ values in Shah and Betts [13] were gathered from various sources which include values scaled from other species (e.g., dog) [18] and/or measured by different techniques (e.g., radiolabeled albumin) [65]. Another possible source of variability in various measured $V_{\mathrm{v}}$ values may be due to circadian effects, which have been reported in nude mice where ranges of $\sim 70-200$, 50-100, and 60-180 $\mu \mathrm{L} / \mathrm{g}$ in liver, kidney, and lung, respectively, have been observed [32].

We are not aware of any previous reports of tissue-level $V_{\mathrm{i}}$ measurement in non-human primates. Our measured $V_{\mathrm{i}}$ values in most tissues were remarkably consistent across species (Table III) and agreed well with values reported in Shah and Betts [13] (Table S5). Our muscle $V_{\mathrm{i}}$ ranged from 48 to $108 \mu \mathrm{L} / \mathrm{g}$ which is roughly consistent with previous reports of $\sim 150 \mu \mathrm{L} / \mathrm{g}$ (measured by ${ }^{111} \mathrm{In}-\mathrm{DTPA}$ ) in murine leg muscle [38, 39].

Importantly, blood-brain barrier permeability to ${ }^{111} \mathrm{In}$ DTPA (represented as brain $K_{\mathrm{p}}$ ) in monkeys was much lower than that in rodents (Fig. 2). The observed 5-10-fold discrepancy is consistent with previous reports of brain antibody concentrations reaching only $0.01-0.02 \%$ of steadystate serum concentrations in cynomolgus monkeys [66, 67], in contrast with reports of $0.1 \%$ in mice [68]. Although it is possible that these interspecies differences in apparent antibody BBB permeability could be due to differences in binding affinity of the antibody $\mathrm{Fc}$ region for the neonatal Fc receptor, our results here suggest that more fundamental differences in BBB permeability may exist between species since we used a non-FcRn-binding small molecule probe ( ${ }^{111}$ In-DTPA) to measure $K_{\mathrm{p}}$. This finding is of great significance in the development of drugs for neurological diseases, as it has significant implications with respect to our ability to translate brain PK/PD data across species. Simply 
Table IV. Measured Organ-Level Blood Flow Rates $(Q)$ in Various Laboratory Animal Species. All Values Were Measured by the Same ${ }^{86} \mathrm{Rb}$ Probe Method. Each Study Is $N=5$ Animals per Group Unless Otherwise Noted. Values in Brackets Indicate Data from a Second Independent Study. Data from Individual Animals, for Cynomolgus Monkey Only, Are Available in Supplementary Table S7

\begin{tabular}{|c|c|c|c|c|c|c|c|}
\hline \multicolumn{8}{|c|}{ Mean $Q(\mu \mathrm{L} / \mathrm{g} / \mathrm{min})$} \\
\hline Tissue & $\begin{array}{l}\text { Monkey } \\
\text { Cynomolgus } \\
\text { (current } \\
\text { manuscript) } \\
N=3\end{array}$ & $\begin{array}{l}\text { Rat } \\
\text { Sprague-Dawley [28] }\end{array}$ & $\begin{array}{l}\text { Mouse } \\
\text { DBA/2 }[28,26]\end{array}$ & $\begin{array}{l}\text { Mouse } \\
\text { C57/B16 } \\
\text { Study } 1 \\
{[28,26]} \\
\text { [study 2] [27] } \\
(N=4, \text { both studies })\end{array}$ & $\begin{array}{l}\text { Mouse } \\
\text { B6SJL-Tg } \\
\text { (SOD1) } \\
\text { 2Gur/J [23] }\end{array}$ & $\begin{array}{l}\text { Mouse } \\
\text { Beige nude } \\
\text { XID }[22,21]\end{array}$ & $\begin{array}{l}\text { Mouse } \\
\text { C.B-17 } \\
\text { SCID beige } \\
\text { (female) }[24]\end{array}$ \\
\hline SM intestine & $332 \pm 94$ & $992 \pm 338$ & $863 \pm 114$ & $\begin{array}{l}388 \pm 89 \\
{[464 \pm 19]}\end{array}$ & $320 \pm 168$ & $380 \pm 136$ & $289 \pm 36$ \\
\hline LG intestine & $458 \pm 209$ & $830 \pm 361$ & $520 \pm 40$ & $263 \pm 34$ & $\mathrm{n} / \mathrm{a}$ & $\mathrm{n} / \mathrm{a}$ & $\mathrm{n} / \mathrm{a}$ \\
\hline Lung & $570 \pm 115$ & $353 \pm 58$ & $544 \pm 216$ & $\begin{array}{l}590 \pm 74 \\
{[843 \pm 73]}\end{array}$ & $721 \pm 86$ & $538 \pm 150$ & $707 \pm 129$ \\
\hline Liver & $416 \pm 164$ & $273 \pm 50$ & $250 \pm 28$ & $\begin{array}{l}137 \pm 17 \\
{[279 \pm 48]}\end{array}$ & $109 \pm 27$ & $158 \pm 20$ & $219 \pm 33$ \\
\hline Kidneys & $3365 \pm 961$ & $3771 \pm 1509$ & $2853 \pm 551$ & $\begin{array}{l}1920 \pm 196 \\
{[2492 \pm 251]}\end{array}$ & $1050 \pm 331$ & $1172 \pm 419$ & $1622 \pm 210$ \\
\hline Heart & $1730 \pm 153$ & $1723 \pm 216$ & $1247 \pm 101$ & $\begin{array}{l}904 \pm 37 \\
{[1463 \pm 185]}\end{array}$ & $1549 \pm 164$ & $877 \pm 63$ & $1227 \pm 240$ \\
\hline Spleen & $471 \pm 99$ & $572 \pm 134$ & $326 \pm 43$ & $\begin{array}{l}163 \pm 23 \\
{[324 \pm 28]}\end{array}$ & $124 \pm 51$ & $169 \pm 105$ & $134 \pm 27$ \\
\hline Muscle & $231 \pm 54$ & $190 \pm 38$ & $200 \pm 43$ & $\begin{array}{l}285 \pm 50 \\
{[217 \pm 35]}\end{array}$ & $300 \pm 34$ & $186 \pm 47$ & $203 \pm 38$ \\
\hline Fat & $155 \pm 31$ & $72 \pm 34$ & $86 \pm 65$ & $45 \pm 18$ & $\mathrm{n} / \mathrm{a}$ & $120 \pm 37$ & $102 \pm 45$ \\
\hline Skin & $93 \pm 23$ & $142 \pm 9$ & $99 \pm 52$ & $\begin{array}{l}116 \pm 21 \\
{[160 \pm 32]}\end{array}$ & $171 \pm 22$ & $\mathrm{n} / \mathrm{a}$ & $101 \pm 29$ \\
\hline Stomach & $\mathrm{n} / \mathrm{a}$ & $561 \pm 79$ & $241 \pm 39$ & $228 \pm 27$ & $\mathrm{n} / \mathrm{a}$ & $\mathrm{n} / \mathrm{a}$ & $\mathrm{n} / \mathrm{a}$ \\
\hline Thymus & $\mathrm{n} / \mathrm{a}$ & $381 \pm 68$ & $237 \pm 99$ & $141 \pm 17$ & $\mathrm{n} / \mathrm{a}$ & $\mathrm{n} / \mathrm{a}$ & $\mathrm{n} / \mathrm{a}$ \\
\hline Pancreas & $\mathrm{n} / \mathrm{a}$ & $756 \pm 138$ & $337 \pm 177$ & $258 \pm 45$ & $\mathrm{n} / \mathrm{a}$ & $\mathrm{n} / \mathrm{a}$ & $\mathrm{n} / \mathrm{a}$ \\
\hline Lymph node & $\mathrm{n} / \mathrm{a}$ & $219 \pm 98$ & $381 \pm 229$ & $137 \pm 9$ & $\mathrm{n} / \mathrm{a}$ & $\mathrm{n} / \mathrm{a}$ & $\mathrm{n} / \mathrm{a}$ \\
\hline Ovaries & $\mathrm{n} / \mathrm{a}$ & $797 \pm 43$ & $\mathrm{n} / \mathrm{a}$ & $\mathrm{n} / \mathrm{a}$ & $\mathrm{n} / \mathrm{a}$ & $\mathrm{n} / \mathrm{a}$ & $\mathrm{n} / \mathrm{a}$ \\
\hline
\end{tabular}

$S M$, small; $L G$, large; $n / a$, not available

scaling from mouse or rat to monkey and human in physiologically based models may exaggerate the ability of antibodies and other drugs with low brain partitioning to reach the site of action.
Our measured $Q$ values in small intestine, large intestine, liver, kidneys, heart, and spleen agreed reasonably well with previously measured values in cynomolgus monkey (using radiolabeled microspheres) reported by Gelman et al.

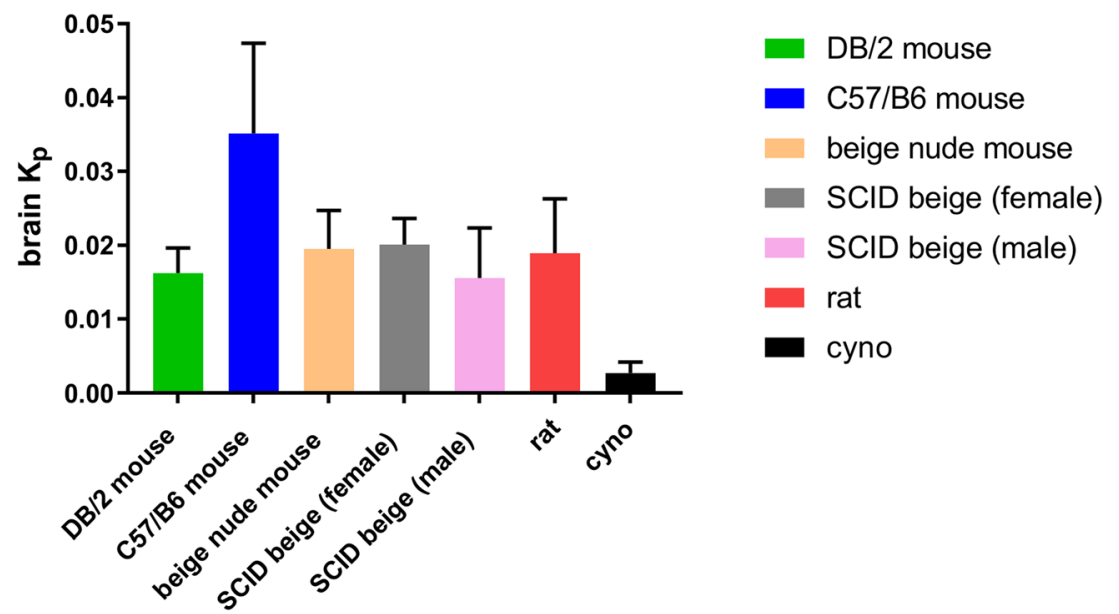

Fig. 2. Species dependence of brain partitioning. Blood-corrected brain/plasma partitioning coefficient $\left(K_{\mathrm{p}}\right)$ for ${ }^{111}$ In-DTPA as a measure of blood-brain integrity in cynomolgus monkeys determined in this study, compared to tissues from other laboratory animal species (Sprague-Dawley rat and various mouse strains) measured previously 

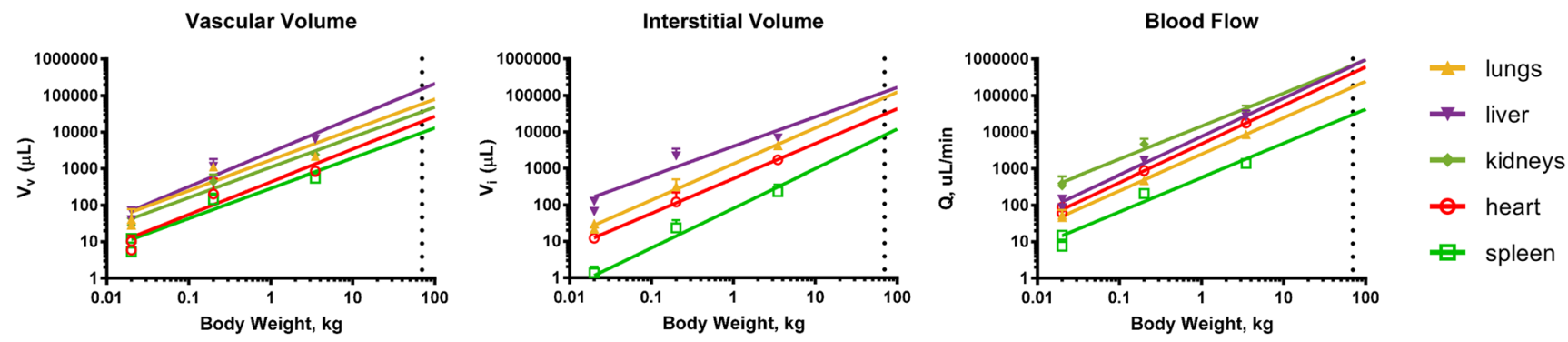

Fig. 3. Allometric plots for $V_{\mathrm{v}}, V_{\mathrm{i}}$, and $\mathrm{Q}$. Vascular volume $\left(V_{\mathrm{v}}\right)$, interstitial volume $\left(V_{\mathrm{i}}\right)$, and blood flow $(Q)$ allometric plots of selected organs in mouse (C57-B16 and DBA/2), rat (Sprague-Dawley), and monkey (cynomolgus, Chinese origin). Parameters (individual points) with standard deviation are shown with fitted linear regression lines. A dotted vertical line at $70 \mathrm{~kg}$ indicates extrapolation to human values

(Table IV, column 1) [69]. Compared to rhesus monkey results reported by Forsyth et al. (also using microspheres) [56], our $Q$ values for skin, heart, small intestine, large intestine, spleen, and kidney also agreed reasonably well (Table IV, column 1); however, our $Q$ values in lung and liver of 570 and $416 \mu \mathrm{L} / \mathrm{g} / \mathrm{min}$ were higher than the reported rhesus values of 180 and 340 [56]. Interestingly, $Q$ values in liver and spleen trended higher in monkey than in mice (as did rat $Q$ values), but were comparable to rodent values in muscle and skin (Table IV). Our muscle $Q$ values of 200 and $190 \mu \mathrm{L} / \mathrm{g} /$ min in mice and rats agreed well with previously reported values of 236 and 237, respectively [20]. Similarly, our skin $Q$ values of 99 and $142 \mu \mathrm{L} / \mathrm{g} / \mathrm{min}$ agreed reasonably well with previously reported values of 185 and 141 in mice and rats, respectively [20]. Compared to values assembled by Shah and Betts [13], the following were observed: (1) our heart $Q$ values were lower in rodents, but higher in monkey (Table S6), (2) our lung $Q$ values could not be directly compared since lung $Q$ is defined as total cardiac output, and (3) our muscle and adipose $Q$ values were each roughly 6-fold higher than the respective values in monkey. Unfortunately, we were unable to ascertain the method(s) by which $Q$ values in Shah and Betts [13] were measured or derived.

Our measured monkey BV of $47.7 \pm 0.7$ (Table I) is lower than the range of $55-75 \mathrm{~mL} / \mathrm{kg}$ reported for cynomolgus monkey [70]. It is, however, within the measured range for rhesus monkeys (44-67 mL/kg) [70] despite being considerably lower than a value of $\sim 149 \mathrm{~mL} / \mathrm{kg}$ previously used for PBPK modeling [12]. Although weight-normalized BVs were identical between monkeys and rats, they were consistently higher for mice (Table I). Furthermore, immunocompromised strains (nude and SCID) had higher BVs than immunocompetent strains, a trend that has not previously been noted to our knowledge. Our measured rat BV of $48 \pm 2 \mathrm{~mL} / \mathrm{kg}$ is lower than previous reports of $\sim 64 \mathrm{~mL} / \mathrm{kg}$ (measured, range 58-70) [34, 70] and $74 \mathrm{~mL} / \mathrm{kg}$ (previously used for PBPK modeling) [12]. Importantly, BV values are highly dependent

Table V. Human $V_{\mathrm{v}}, V_{\mathrm{i}}$, and $Q$ Values Extrapolated from Allometric Analysis of Preclinical Data in Mouse, Rat, and Monkey

\begin{tabular}{cccccc}
\hline & Lung & Liver & Kidney & Heart & Spleen \\
\hline$V_{\mathrm{v}}(\mu \mathrm{L} / \mathrm{g})$ & 59 & 84 & 116 & 59 & 53 \\
$V_{\mathrm{i}}(\mu \mathrm{L} / \mathrm{g})$ & 87 & 70 & $\mathrm{n} / \mathrm{a}$ & 93 & 45 \\
$Q(\mu \mathrm{L} / \mathrm{g} / \mathrm{min})$ & 173 & 366 & 2188 & 1273 & 169 \\
\hline
\end{tabular}

$n / a$, not available on measurement method as values of $\sim 94$ and $\sim 65 \mathrm{~mL} / \mathrm{kg}$ were reported for rats using ${ }^{131} \mathrm{I}$-labeled albumin and ${ }^{51} \mathrm{Cr}$ labeled RBCs, respectively [35]. Our measured values in mice $(60 \pm 9$ to $109 \pm 4 \mathrm{~mL} / \mathrm{kg}$ ) are roughly consistent with a previously reported range of $85-95 \mathrm{~mL} / \mathrm{kg}$ in CSI and CBA mice [71]. Others have noted differences in mouse BV depending on methodology, with values of 50-59 and 73$103 \mathrm{~mL} / \mathrm{kg}$ using ${ }^{59} \mathrm{Fe}$-labeled $\mathrm{RBCs}$ and ${ }^{59} \mathrm{Fe}$-labeled transferrin, respectively [72]. These two ${ }^{59} \mathrm{Fe}$-labeling-based techniques also led to distinct ranges for venous (0.47 to 0.52$)$ and whole-body (0.30 to 0.34$)$ hematocrits in mice [72], with similar trends in rats [35] and humans [73-76]. Differences between venous and whole-body hematocrits have been attributed in part to the spleen acting as a reservoir for RBCs [77], and a similar mechanism may influence BV measurements. Blood has been reported to constitute 4.9, 7.4, and $7.9 \%$ of body weight in mice, rats, and humans, respectively, equivalent to 49,74 , and $79 \mathrm{~mL} / \mathrm{kg}$ (assuming density of $1 \mathrm{~g} /$ $\mathrm{mL}$ ) [18]. However, our data seem to indicate an opposite trend, with lower body weight-normalized volumes of blood in higher species, roughly consistent with values of approximately 78 and $55 \mathrm{~mL} / \mathrm{kg}$ reported for mouse and rat, respectively [20]. Furthermore, our results are roughly consistent with a previously reported allometric scaling method in which blood weight is equal to 0.055 multiplied by body weight to the power of 0.99 [1].

Overall, our allometric analysis revealed the expected body weight dependence of $V_{\mathrm{v}}, V_{\mathrm{i}}$, and $Q$ (Fig. 3). Scaling exponents for $V_{\mathrm{i}}$ and $V_{\mathrm{v}}$ suggest that lung and liver vary near body weight proportionally, while spleen has a more shallow slope with respect to BW (Table S2). The extrapolated human $Q$ values of 366, 2188, 1273 , and $169 \mu \mathrm{L} / \mathrm{g} / \mathrm{min}$ in liver, kidney, heart, and spleen (Table V) were lower (except heart) than human values of $806,4000,727$, and 428 reported in Davies and Morris [52]. Note that $Q$ values were calculated from $\mathrm{CO}$ values $(8,74$, and $1086 \mathrm{~mL} / \mathrm{min}$ for a $0.02-\mathrm{kg}$ mouse, $0.25-\mathrm{kg}$ rat, and 5-kg monkey, respectively) obtained from a separate report [52] in which $\mathrm{CO}$ (at least one of which is a measured value [56]) scales with an exponent of $\sim 0.9$.

One technical challenge we faced was that the size of monkey tissues limits the ability to analyze whole tissues by solid scintillation (i.e., gamma) counting as was previously done for most mouse and rat organs. One possible approach was to collect representative sections; however, we were concerned that the complex structures of organs like brain, heart, kidneys, and lungs might introduce bias into our measurements if the section analyzed did not accurately represent the organ as a whole. As such, these entire organs were homogenized so that aliquots could be counted. In contrast, the 
representative sectioning approach (in duplicate, to minimize bias) was applied to intestines (ileum and colon), muscle, fat, and skin. It should be noted that representative sections of these tissues were also used to derive our previous parameter values in rodents.

A second scaling challenge was the large blood volume of monkeys (approximately $180 \mathrm{~mL}$ ), which diluted the ${ }^{99 \mathrm{~m}} \mathrm{Tc}$ activity in our in vivo RBC labeling/transfusion protocol to such an extent that this method would have required working with excessive amounts of radioactivity to maintain sufficient gamma counting sensitivity. To address this challenge, we adapted an alternative in vivo/in vitro clinical protocol [78] in which pre-tinning is accomplished in vivo while ${ }^{99 \mathrm{~m}} \mathrm{TcO}^{4-}$ labeling is accomplished in vitro but without requiring centrifugation to preserve the integrity of RBCs. To ensure that our data in monkeys can be compared to our previous data in rodents, we ensured that non-RBC-associated levels of ${ }^{99 \mathrm{~m}} \mathrm{Tc}$ were low by centrifuging aliquots and counting plasma and pellets separately. Furthermore, any damage to RBCs would likely result in elevated uptake in spleen (the sequestration site for damaged or aging RBCs); however, spleen $V_{\mathrm{v}}$ values were similar between monkey and rodents (Table II), suggesting that RBC damage did not occur.

\section{CONCLUSION}

In summary, our work addresses the limited availability of tissue-level physiological parameters in primates in the literature, and our allometric analysis approach allowed extrapolation of human $V_{\mathrm{v}}, V_{\mathrm{i}}$, and $Q$ values based on preclinical knowledge. While the majority of our measured values agree well with previously published values [13], some differed by as much as 6-fold which, particularly in the case of large tissues, may be impactful as illustrated by sensitivity analysis which shows that PBPK model simulations are very sensitive to changes in $V_{\mathrm{v}}$. The finding that the blood-brain barrier was more impervious to intravenously infused ${ }^{111}$ In-DTPA in monkey than in rodents was surprising and warrants further investigation, as does the observed trend towards higher weight-normalized blood volumes in immunocompromised mice relative to immunocompetent strains. Overall, the data herein support previous assumptions that $V_{\mathrm{v}}, V_{\mathrm{i}}$, and $Q$ in tissues are roughly body weight proportional across species, but that tissuespecific deviations warrant the use of measured, species-specific values.

\section{ACKNOWLEDGEMENTS}

All studies were internally funded by Genentech, a member of the Roche Group. We thank Ruedi Port and Daniela Bumbaca Yadav for scientific discussions and Bernadette Johnstone, Cynthia Young, Elizabeth Torres, Jason Ho, Jose Imperio, Kirsten Messick, Nicole Valle, Nina Ljumanovic, Roxanne Kyauk, Shannon Stainton, and Eduardo Mundo for technical assistance with animal studies.

Open Access This article is distributed under the terms of the Creative Commons Attribution 4.0 International License (http://creativecommons.org/licenses/by/4.0/), which permits unrestricted use, distribution, and reproduction in any medium, provided you give appropriate credit to the original author(s) and the source, provide a link to the Creative Commons license, and indicate if changes were made.

\section{REFERENCES}

1. Adolph EF. Quantitative relations in the physiological constitutions of mammals. Science. 1949;109(2841):579-85.

2. Dedrick RL. Animal scale-up. J Pharmacokinet Biopharm. 1973;1(5):435-61.

3. McMahon T. Size and shape in biology. Science. 1973;179(4079):1201-4.

4. Mordenti J. Man versus beast: pharmacokinetic scaling in mammals. J Pharm Sci. 1986;75(11):1028-40.

5. Huang Q, Riviere JE. The application of allometric scaling principles to predict pharmacokinetic parameters across species. Expert Opin Drug Metab Toxicol. 2014;10(9):1241-53.

6. Mordenti J, Chen SA, Moore JA, Ferraiolo BL, Green JD. Interspecies scaling of clearance and volume of distribution data for five therapeutic proteins. Pharm Res. 1991;8(11):1351-9.

7. Eigenmann MJ, Karlsen TV, Krippendorff BF, Tenstad O, Fronton L, Otteneder MB, et al. Interstitial $\operatorname{IgG}$ antibody pharmacokinetics assessed by combined in vivo- and physiologically-based pharmacokinetic modelling approaches. J Physiol. 2017;595(24):7311-30.

8. Boswell CA, Bumbaca D, Fielder PJ, Khawli LA. Compartmental tissue distribution of antibody therapeutics: experimental approaches and interpretations. AAPS J. 2012;14(3):612-8.

9. Benias PC, Wells RG, Sackey-Aboagye B, Klavan H, Reidy J, Buonocore D, et al. Structure and distribution of an unrecognized interstitium in human tissues. Sci Rep. 2018;8(1):4947.

10. Ferl GZ, Wu AM, DiStefano JJ 3rd. A predictive model of therapeutic monoclonal antibody dynamics and regulation by the neonatal Fc receptor (FcRn). Ann Biomed Eng. 2005;33(11):1640-52.

11. Gerlowski LE, Jain RK. Physiologically based pharmacokinetic modeling: principles and applications. J Pharm Sci. 1983;72(10):1103-27.

12. Hall C, Lueshen E, Mosat A, Linninger AA. Interspecies scaling in pharmacokinetics: a novel whole-body physiologically based modeling framework to discover drug biodistribution mechanisms in vivo. J Pharm Sci. 2012;101(3):1221-41.

13. Shah DK, Betts AM. Towards a platform PBPK model to characterize the plasma and tissue disposition of monoclonal antibodies in preclinical species and human. J Pharmacokinet Pharmacodyn. 2012;39(1):67-86.

14. Zhao J, Cao Y, Jusko WJ. Across-species scaling of monoclonal antibody pharmacokinetics using a minimal PBPK model. Pharm Res. 2015;32(10):3269-81.

15. Garg A, Balthasar JP. Physiologically-based pharmacokinetic (PBPK) model to predict IgG tissue kinetics in wild-type and FcRn-knockout mice. J Pharmacokinet Pharmacodyn. 2007;34(5):687-709.

16. Baxter LT, Zhu H, Mackensen DG, Butler WF, Jain RK. Biodistribution of monoclonal antibodies: scale-up from mouse to human using a physiologically based pharmacokinetic model. Cancer Res. 1995;55(20):4611-22.

17. Baxter LT, Zhu H, Mackensen DG, Jain RK. Physiologically based pharmacokinetic model for specific and nonspecific monoclonal antibodies and fragments in normal tissues and human tumor xenografts in nude mice. Cancer Res. 1994;54(6):1517-28.

18. Brown RP, Delp MD, Lindstedt SL, Rhomberg LR, Beliles RP. Physiological parameter values for physiologically based pharmacokinetic models. Toxicol Ind Health. 1997;13(4):407-84.

19. Hu TM, Hayton WL. Allometric scaling of xenobiotic clearance: uncertainty versus universality. AAPS PharmSciTech. 2001;3(4):E29.

20. Lindstedt SL, Schaeffer PJ. Use of allometry in predicting anatomical and physiological parameters of mammals. Lab Anim. 2002;36(1):1-19.

21. Boswell CA, Ferl GZ, Mundo EE, Bumbaca D, Schweiger MG, Theil FP, et al. Effects of anti-VEGF on predicted antibody biodistribution: roles of vascular volume, interstitial volume, and blood flow. PLoS One. 2011;6(3):e17874. https://doi.org/ 10.1371/journal.pone.0017874. 
22. Boswell CA, Ferl GZ, Mundo EE, Schweiger MG, Marik J, Reich MP, et al. Development and evaluation of a novel method for preclinical measurement of tissue vascular volume. Mol Pharm. 2010;7(5):1848-57.

23. Boswell CA, Mundo EE, Johnstone B, Ulufatu S, Schweiger MG, Bumbaca D, et al. Vascular physiology and protein disposition in a preclinical model of neurodegeneration. Mol Pharm. 2013;10(5):1514-21.

24. Pastuskovas CV, Mundo EE, Williams SP, Nayak TK, Ho J, Ulufatu S, et al. Effects of anti-VEGF on pharmacokinetics, biodistribution, and tumor penetration of trastuzumab in a preclinical breast cancer model. Mol Cancer Ther. 2012;11(3):752-62.

25. Boswell CA, Mundo EE, Zhang C, Stainton SL, Yu SF, Lacap JA, et al. Differential effects of predosing on tumor and tissue uptake of an ${ }^{111}$ In-labeled anti-TENB2 antibody-drug conjugate. J Nucl Med. 2012;53(9):1454-61. https://doi.org/10.2967/ jnumed.112.103168.

26. Deng R, Bumbaca D, Pastuskovas CV, Boswell CA, West D, Cowan KJ, et al. Preclinical pharmacokinetics, pharmacodynamics, tissue distribution, and tumor penetration of anti-PD-L1 monoclonal antibody, an immune checkpoint inhibitor. MAbs. 2016;8(3):593-603.

27. Bien-Ly N, Boswell CA, Jeet S, Beach TG, Hoyte K, Luk W, et al. Lack of widespread BBB disruption in Alzheimer's disease models: focus on therapeutic antibodies. Neuron. 2015;88(2):289-97.

28. Boswell CA, Mundo EE, Ulufatu S, Bumbaca D, Cahaya HS, Majidy N, et al. Comparative physiology of mice and rats: radiometric measurement of vascular parameters in rodent tissues. Mol Pharm. 2014;11(5):1591-8.

29. Manzone TA, Dam HQ, Soltis D, Sagar VV. Blood volume analysis: a new technique and new clinical interest reinvigorate a classic study. J Nucl Med Technol. 2007;35(2):55-63 quiz $77,9$.

30. Rehani MM, Sharma SK. Site of Tc- $99 \mathrm{~m}$ binding to the red blood cell: concise communication. J Nucl Med. 1980;21(7):676-8.

31. Pavel DG, Zimmer M, Patterson VN. In vivo labeling of red blood cells with ${ }^{99 \mathrm{~m}} \mathrm{Tc}$ : a new approach to blood pool visualization. J Nucl Med. 1977;18(3):305-8.

32. Blumenthal RD, Osorio L, Ochakovskaya R, Ying Z, Goldenberg DM. Regulation of tumour drug delivery by blood flow chronobiology. Eur J Cancer. 2000;36(14):1876-84.

33. Klein HG. Mollison's blood transfusion in clinical medicine. In: Mollison PL, Anstee DJ, Mollison PL, editors. 11th ed. ed. Malden, Mass. Blackwell Pub.; 2005.

34. Lee HB, Blaufox MD. Blood volume in the rat. J Nucl Med. 1985;26(1):72-6.

35. Berman I, Carr R, Malone E. Determination of total blood volume from measurements of total red blood cell mass and plasma volume, using simultaneously injected isotopes. Nature. 1964;202:1013-5.

36. Aukland K, Reed RK. Interstitial-lymphatic mechanisms in the control of extracellular fluid volume. Physiol Rev. 1993;73(1):1-78.

37. Levitt DG. The pharmacokinetics of the interstitial space in humans. BMC Clin Pharmacol. 2003;3(3):3.

38. Shockley TR, Lin K, Sung C, Nagy JA, Tompkins RG, Dedrick RL, et al. A quantitative analysis of tumor specific monoclonal antibody uptake by human melanoma xenografts: effects of antibody immunological properties and tumor antigen expression levels. Cancer Res. 1992;52(2):357-66.

39. Sung C, Youle RJ, Dedrick RL. Pharmacokinetic analysis of immunotoxin uptake in solid tumors: role of plasma kinetics, capillary permeability, and binding. Cancer Res. 1990;50(22):7382-92.

40. Kallman RF, DeNardo GL, Stasch MJ. Blood flow in irradiated mouse sarcoma as determined by the clearance of xenon-133. Cancer Res. 1972:32(3):483-90.

41. Sapirstein LA. Regional blood flow by fractional distribution of indicators. Am J Phys. 1958;193(1):161-8.

42. Gullino PM, Grantham FH. Studies on the exchange of fluids between host and tumor. III. Regulation of blood flow in hepatomas and other rat tumors. J Natl Cancer Inst. 1962:28:211-29.
43. Hammersley PA, McCready VR, Babich JW, Coghlan G. ${ }^{99 \mathrm{~m}} \mathrm{Tc}-$ HMPAO as a tumour blood flow agent. Eur J Nucl Med. 1987;13(2):90-4.

44. Zanelli GD, Fowler JF. The measurement of blood perfusion in experimental tumors by uptake of ${ }^{86} \mathrm{Rb}$. Cancer Res. 1974;34(6):1451-6.

45. Cherry SR, Carnochan P, Babich JW, Serafini F, Rowell NP, Watson IA. Quantitative in vivo measurements of tumor perfusion using rubidium-81 and positron emission tomography. J Nucl Med. 1990;31(8):1307-15.

46. Mossberg KA, Mullani N, Gould KL, Taegtmeyer H. Skeletal muscle blood flow in vivo: detection with rubidium-82 and effects of glucose, insulin, and exercise. J Nucl Med. 1987;28(7):1155-63.

47. Hagemann CE, Ghotbi AA, Kjær A, Hasbak P. Quantitative myocardial blood flow with Rubidium-82 PET: a clinical perspective. Am J Nucl Med Mol Imaging. 2015;5(5):457-68.

48. Mendell PL, Hollenberg NK. Cardiac output distribution in the rat: comparison of rubidium and microsphere methods. Am J Phys. 1971;221(6):1617-20.

49. Gabrielsson J, Weiner D. Pharmacokinetic and pharmacodynamic data analysis: concepts and applications 2016.

50. Brooks DJ, Beaney RP, Lammertsma AA, Leenders KL, Horlock PL, Kensett MJ, et al. Quantitative measurement of blood-brain barrier permeability using rubidium-82 and positron emission tomography. J Cereb Blood Flow Metab. 1984;4(4):535-45.

51. Urva SR, Yang VC, Balthasar JP. Physiologically based pharmacokinetic model for T84.66: a monoclonal anti-CEA antibody. J Pharm Sci. 2010;99(3):1582-600.

52. Davies B, Morris T. Physiological parameters in laboratory animals and humans. Pharm Res. 1993;10(7):1093-5.

53. Graf JF, Scholz BJ, Zavodszky MI. BioDMET: a physiologically based pharmacokinetic simulation tool for assessing proposed solutions to complex biological problems. J Pharmacokinet Pharmacodyn. 2012;39(1):37-54.

54. Sands H, Jones PL, Shah SA, Palme D, Vessella RL, Gallagher BM. Correlation of vascular permeability and blood flow with monoclonal antibody uptake by human Clouser and renal cell xenografts. Cancer Res. 1988;48(1):188-93.

55. Sands H, Shah SA, Gallagher BM. Vascular volume and permeability of human and murine tumors grown in athymic mice. Cancer Lett. 1985;27(1):15-21.

56. Forsyth RP, Nies AS, Wyler F, Neutze J, Melmon KL. Normal distribution of cardiac output in the unanesthetized, restrained rhesus monkey. J Appl Physiol. 1968;25(6):736-41.

57. Jilkina O, Xiang B, Kuzio B, Rendell J, Kupriyanov VV. Potassium transport in Langendorff-perfused mouse hearts assessed by $87 \mathrm{Rb}$ NMR spectroscopy. Magn Reson Med. 2005;53(5):1172-6.

58. Evans MV, Dowd SM, Kenyon EM, Hughes MF, El-Masri HA. A physiologically based pharmacokinetic model for intravenous and ingested dimethylarsinic acid in mice. Toxicol Sci. 2008;104(2):250-60.

59. Kim C-Y, Han JS, Suzuki T, Han S-S. Indirect indicator of transport stress in hematological values in newly acquired cynomolgus monkeys. J Med Primatol. 2005;34(4):188-92.

60. Rosso MC, Badino P, Ferrero G, Costa R, Cordero F, Steidler S. Biologic data of cynomolgus monkeys maintained under laboratory conditions. PLoS One. 2016;11(6):e0157003.

61. Khor SP, Bozigian H, Mayersohn M. Potential error in the measurement of tissue to blood distribution coefficients in physiological pharmacokinetic modeling. Residual tissue blood. II. Distribution of phencyclidine in the rat. Drug Metab Dispos. 1991;19(2):486-90.

62. Lockman PR, McAfee G, Geldenhuys WJ, Van der Schyf CJ, Abbruscato TJ, Allen DD. Brain uptake kinetics of nicotine and cotinine after chronic nicotine exposure. J Pharmacol Exp Ther. 2005;314(2):636-42.

63. Park S, Sinko PJ. P-glycoprotein and mutlidrug resistanceassociated proteins limit the brain uptake of saquinavir in mice. J Pharmacol Exp Ther. 2005;312(3):1249-56.

64. O'Connor SW, Bale WF. Accessibility of circulating immunoglobulin $G$ to the extravascular compartment of solid rat tumors. Cancer Res. 1984;44(9):3719-23. 
65. Triplett JW, Hayden TL, McWhorter LK, Gautam SR, Kim EE, Bourne DW. Determination of gallium concentration in "bloodfree" tissues using a radiolabeled blood marker. J Pharm Sci. 1985;74(9):1007-9.

66. Yadav DB, Maloney JA, Wildsmith KR, Fuji RN, Meilandt WJ, Solanoy $\mathrm{H}$, et al. Widespread brain distribution and activity following i.c.v. infusion of anti-beta-secretase (BACE1) in nonhuman primates. Br J Pharmacol. 2017;174(22):4173-85.

67. Yu YJ, Atwal JK, Zhang Y, Tong RK, Wildsmith KR, Tan C, et al. Therapeutic bispecific antibodies cross the blood-brain barrier in nonhuman primates. Sci Transl Med. 2014;6(261):261ra154.

68. Atwal JK, Chen Y, Chiu C, Mortensen DL, Meilandt WJ, Liu Y, et al. A therapeutic antibody targeting BACE1 inhibits amyloidbeta production in vivo. Sci Transl Med. 2011;3(84):84ra43.

69. Gelman S, Fowler KC, Bishop SP, Smith LR. Cardiac output distribution and regional blood flow during hypocarbia in monkeys. J Appl Physiol (Bethesda, Md : 1985.). 1985;58(4):1225-30.

70. Diehl KH, Hull R, Morton D, Pfister R, Rabemampianina Y, Smith D, et al. A good practice guide to the administration of substances and removal of blood, including routes and volumes. J Appl Toxicol. 2001;21(1):15-23.

71. Riches AC, Sharp JG, Thomas DB, Smith SV. Blood volume determination in the mouse. J Physiol. 1973;228(2):279-84.
72. Vacha J. Blood volume in inbred strain BALB/c, CBA/J and C57BL/10 mice determined by means of ${ }^{59} \mathrm{Fe}$-labelled red cells and ${ }^{59} \mathrm{Fe}$ bound to transferrin. Physiologia Bohemoslovaca. 1975;24(5):413-9.

73. Chaplin H Jr, Mollison PL, Vetter H. The body/venous hematocrit ratio: its constancy over a wide hematocrit range. J Clin Invest. 1953;32(12):1309-16.

74. Giannelli S Jr, Ayres SM, Fleming P, Conrad W, Schwartz MS, Gould H. Peripheral vascular volumes and whole body hematocrit during human heart lung bypass. Circulation. 1970;41(4):629-40.

75. Kirsch KA, Johnson RF, Gorten RJ. The significance of the total-body hematocrit in measurements of blood compartments. J Nucl Med. 1971;12(1):17-21.

76. Fairbanks VF, Klee GG, Wiseman GA, Hoyer JD, Tefferi A, Petitt RM, et al. Measurement of blood volume and red cell mass: re-examination of ${ }^{51} \mathrm{Cr}$ and ${ }^{125} \mathrm{I}$ methods. Blood Cells Mol Dis. 1996;22(2):169-86 discussion 86a-86g.

77. Fudenberg H, Baldini M, Mahoney JP, Dameshek W. The body hematocrit/venous hematocrit ratio and the "splenic reservoir". Blood. 1961;17:71-82.

78. Bauer R, Haluszczynski I, Langhammer H, Bachmann W. In vivo/in vitro labeling of red blood cells with ${ }^{99} \mathrm{mTc}$. Eur J Nucl Med. 1983;8(5):218-22. 